\title{
Urban lands for agricultural use: soft manage- ment of the ecology state
}

\author{
M.A. Safonov ${ }^{1, *}, T . I$. Safonova $^{2}$ \\ ${ }^{1}$ Department of Management Theories and Practicess, Russian Presidential Academy of National \\ Economy and Public Administration, Orenburg branch, Kutacha St., 26, Orenburg, 460000, Russia \\ ${ }^{2}$ Department of Biology, Nature Using and Environmental Safety, Orenburg State Agrarian \\ University, Chelyuskintsev St., 18, Orenburg, 460000, Russia
}

\begin{abstract}
Agricultural lands occupy a special place in the structure of urban lands. There are horticultural and gardening associations on these lands. The "belts" of horticultural associations surround large cities and small settlements; dachas and vegetable gardens play the role of individual subsidiary farms and recreation areas. In Russia, the area of such lands is about 1.5 million hectares; in the Orenburg region - 18.7 thousand hectares. Studies show that horticultural ecosystems differ significantly from the adjacent urban and agricultural ecosystems in terms of the characteristics of soil and plant cover. The reason for this is private investment in the development of these territories, which needs to be managed. For the consistent development of these socio-ecological systems (SES), it is necessary to implement a soft management system. The purpose of creating and supporting of socio-ecological systems in the agricultural use zone and suburbs is the formation of a sustainable complex of natural and social conditions for gardening and recreation of residents; optimization of the belt of lands separating the city from agricultural land to reduce the impact of adverse environmental factors on urban ecosystems (wind restriction, fire safety, pests, etc.); use of these lands as carbon polygons for capturing and retaining of carbon dioxide.
\end{abstract}

\section{Introduction}

Urban settlements are a special socio-economic phenomenon; their role in the formation of economic space, transport networks, and the demographic situation in the country is constantly growing due to the global spread of urbanization processes. The attractiveness of cities for residents of small settlements leads to migration to cities and the emergence of an imbalance between urban and rural territories in terms of population size and structure. The continued growth of cities and the addition of new territories to them leads to an increase in the anthropogenic load on urban and suburban ecosystems. Urban ecosystems are characterized by small biodiversity with a predominance of banal and weed species, degeneracy of the soil cover with a high content of technogenic pollutants in the soil, a specific micro-

\footnotetext{
*Corresponding author: safonovmaxim@yandex.ru
} 
climate - higher temperature indicators, uneven precipitation, etc. [18]. These signs are not the same for the entire territory of the city and vary by urban zones.

The lands of cities are zoned based on the peculiarities of their use and development prospects. The structuring of urban areas is associated with certain differences in the mode of using different parts of the urban environment and managing them to achieve the goals of sustainable settlement development $[3,10]$. Along with the industrial zone, the development zone, the recreational zone, there is an agricultural use zone. Most often, these territories were related agricultural lands and belonged to the suburbs, and later entered the city limits with the preservation of some of the functional features - gardening and horticulture is carried out on these lands within the existing horticultural non-profit partnerships (HNP) $[14,15]$. The "belts" of horticultural associations surround large cities and small settlements; dachas and vegetable gardens play the role of individual subsidiary farms and recreation areas [7].

According to the agricultural census of 2016, there were more than 75 thousand horticultural, garden and dacha associations in Russia. The Unified State Register of Real Estate contains information about almost 10 million horticultural and garden plots. At least 3 million more land plots have not yet been registered for various reasons. The total area of garden and vegetable plots can be estimated at about 1.5 million hectares [21]. The number of gardeners and summer residents in the country exceeds 60 million. In the Orenburg Region, according to the data of the Territorial Authority of the Federal State Statistics Service [16], 537 non-profit associations of citizens are registered, which occupy an area of 18.7 thousand hectares and include 234.8 thousand land plots.

Land of agricultural use occupied by dachas and vegetable gardens has its own specifics of nature management: this is an object of investment by individuals who equip their plots, constructing residential buildings and outbuildings, organize planting and take care of them, improve the quality of the soil, etc. It is not possible to estimate the volume of private investment in the development of dacha farms, but they are clearly large and the trend of their growth continues. So, according to the Forbs portal, with a link to the materials of the site Price.ru due to the COVID-19 pandemic, the demand for suburban goods doubled in 2020 compared to 2091, including fertilizers and soils - by $93 \%$, greenhouses - by $15 \%$, goods for water supply of plots - by $9 \%$.

If we do not consider the construction activity of citizens, which is not the main purpose of the existence of suburban areas, then the main impact on the resources of these lands is expressed in the following forms:

- land depletion; to solve this problem, the delivery of soils and humus, the application of mineral and organo-mineral fertilizers is carried out;

- the use of water resources for irrigation, household needs, which leads to an increase in surface and subsurface runoff;

- change in the relief of the original landscape, which changes the air flow of the adjacent territories;

- transformation of the typical flora and fauna as a result of weeds and insect pests' control; expansion of the assortment of cultivated plants with the risk of integration dangerous invasive species into the biota.

It should be noted that all these actions of individuals are spontaneous in nature and are not regulated by local self-government structures and the leadership of the NHP. It can be assumed that where there are such large-scale, vectorized changes in the environment, control and management of such processes are necessary.

The purpose of our study was to assess the level of transformation of the ecological state of the territories occupied by horticultural partnerships, as a basis for brining into 
force soft management of optimization of environmental management in this part of urban lands.

\section{Materials and Methods}

The assessment of changes in the ecological state of the territories occupied by horticultural (dacha) settlements was carried out within the city of Orenburg, the administrative center of the Orenburg region, in the settlements of Rostoshi-1, 2, 3, forming a large array in the north-east-east of the city. For comparison, relevant data were collected in adjacent residential areas and on agricultural land adjacent to suburban areas from the east.

As an indicator of the ecological state of the territory, we chose the characteristics of the soil cover (the amount of humus, $\mathrm{pH}$ and hardness of the soil solution) and the species composition of the vegetation cover. These indicators are selected based on the fact that they are affected by human economic activity.

Soil sampling was carried out in June 2021; a total of 20 bulk samples were taken [5]. In the laboratory, the acid-base properties and hardness of the soil extract were determined using a portable $\mathrm{pH}$ meter and a conductometer. Determination of the amount of humus was carried out by the method of I. Tjurin in the modification of the TSINAO (GOST 26213-91) [17].

The study of the plant cover was carried out by a continuous collection of plants at each of the points with subsequent identification. In the future, plants were catalogued, their ecological characteristics were compared and the representation of individual plant groups was evaluated.

\section{Results and Discussions}

The soil cover of the studied areas is represented by southern chernozems and southern carbonate cultivated and slightly intact chernozems [6]. The analysis showed that the average amount of humus in all soil samples is 4.11 , which allows us to attribute some of the studied soils to fertile (more than 4.0) (Table 1).

Table 1. Amount of humus in soil samples $(\mathrm{g} / \mathrm{kg})$.

\begin{tabular}{|c|c|c|c|}
\hline Plots & $\min$ & $\max$ & Average value \\
\hline 1 (city) & 3.98 & 4.62 & 4.26 \\
\hline 2 (horticultural area) & 3.03 & 4.24 & 3.60 \\
\hline 3 (agricultural lands) & 3.68 & 4.71 & 4.26 \\
\hline
\end{tabular}

At the same time, a significant variation in the humus content by samples was noted within all sites. A comparison of samples using the Fisher criterion showed that the samples of disturbed soils of the city are most clearly different from other samples.

The average $\mathrm{pH}$ of the soil water extract for all sites is 8.4 , i.e. the reaction is alkaline. The greatest similarity in this indicator was noted between the soils of the horticulture lands and agricultural lands.

The hardness of water is a set of its properties, which are determined by the content of dissolved salts of alkali metals in it - hardness salts (primarily calcium and magnesium). The average value of this indicator for soil extracts at the studied sites is $28.8 \mathrm{ppm}$, i.e. 0.6 $\mathrm{mg}$-eq/l. Thus, the water extract according to this characteristic is soft $(<2 \mathrm{mg}$-eq/l).

In the samples at the sites, this indicator also varied significantly - from 12 to $57 \mathrm{ppm}$.

Thus, the soil characteristics of the studied sites differ. As we move away from the residential area, there is a consistent improvement and leveling of the characteristics of the soil 
cover, but the horticultural lands do not fit into this trend, differing from the adjacent territories.

The investigation of the plant cover showed a number of differences in the ecological structure of the floras of urbanized, suburbanized territories and areas with natural vegetation adjacent to the latter (Table 2 ).

Table 2. Comparative characteristics of the flora of the studied sites.

\begin{tabular}{|c|c|c|c|}
\hline \multirow{2}{*}{ Features } & Full flora of & \multicolumn{2}{|c|}{ Flora of zones outside of housing } \\
\cline { 3 - 4 } & Orenburg city & Horticultural land & Agricultural land \\
\hline Number of species & 683 & 179 & 163 \\
\hline $\begin{array}{c}\text { Taxonomic proportions of } \\
\text { flora }\end{array}$ & $1: 3.8: 7.5$ & $1: 3.6: 6.2$ & $1: 3.3: 9.1$ \\
\hline Percentage of mesophytes, \% & 35.6 & 35.8 & 33.7 \\
\hline $\begin{array}{c}\text { Share of adventitious species, } \\
\%\end{array}$ & 35.4 & 43.1 & 16.6 \\
\hline
\end{tabular}

Types of sites differ significantly by the number of species; the maximum diversity is noted on the horticultural territory. For the compared sites which have one or another degree of anthropogenic degradation, the analysis of the representation of weed species is of considerable interest because weed plants are indicators of the level of anthropogenic pressure. According to the number of weed species, the flora of agricultural lands is distinguished. The analysis of the relative share of weed plants showed that weed species make up $20 \%$ of the total number of identified species in the residential area, $13.2 \%$ in the suburban area and $23 \%$ in agricultural land.

The species composition of sites floras has a low similarity. The flora of the horticultural lands differs significantly, where, due to human activity, the conditions are more mesophytic, since gardening is accompanied by watering of plantings. In addition, a significant number of tree plantings, shrubs, the presence of residential buildings and outbuildings leads to additional shading, which creates conditions for the growth of not only cultivated mesophytic plants, but also weeds, and also wild mesophytic ones.

The obtained data allow us to conclude that as we move away from the city, the anthropogenic influence on the vegetation cover weakens, which is expressed in an increase of species diversity, a decrease in the number of weed species, an increase in the proportion of mesophytic and xeromesophytic species. At the same time, the presence of suburban settlements leads to a significant change in floral complexes due to the active intervention of the population in the creation of specific conditions of plants habitats (watering, plowing, fertilizing, etc.).

The conducted studies allow us to conclude that within the zone of agricultural use, a "belt" of atypical habitats with special characteristics of the soil cover and with an increased diversity of flora is being created around the city due to the active formation of subsidized cultural and quasi-natural ecosystems by the population.

The specifics of the ecological status of this area of the city determines the need to manage its development. In article 26 of Federal Law No. 217-FZ of 29.07.2017 (ed. dated 22.12.2020) "On the conduct of gardening and horticulture by citizens for their own needs and on amendments to certain legislative acts of the Russian Federation", the special social significance of gardening and horticulture is noted, and the rights of government agencies of the subjects of the Russian Federation and local self-government agencies to support gardening and horticulture, including in terms of creating investment programs, are clarified.

For a regulating the support of gardening and horticulture a number of regional laws were adopted, for example, the regional Law of the Krasnoyarsk Krai No. 8-3140 of February 12, 2015 "On state support of gardening and horticulture in the Krasnoyarsk Krai". In 
the Orenburg Region, state support for horticultural, gardening and dacha non-profit associations is carried out within the framework of Federal Law No. 217-FZ, the state program "Development of agriculture and regulation of markets of agricultural products, raw materials and food of the Orenburg Region" and the decree of the Government of the Orenburg Region dated 28.04.2018 No. 256-p "On the procedure for providing subsidies for reimbursement of part of the costs of engineering support for the territories of horticultural, gardening and dacha non-profit associations of citizens". So, in 2020, 11 horticultural and gardening non-profit associations received state support in the amount of 2.8 million rubles.

In the structure of the administrations of some municipalities, there are specialized departments engaged in the development of horticulture, for example, the Department for the Development of Gardening and Horticulture of the Administration of St. Petersburg, etc. In Orenburg, the Department of Land Use and Development of Suburban Economy of the administration deals with such issues.

Most of the activities from the administrative structures are represented by the regulation of urgent or controversial issues related to the development of the infrastructure of non-profit partnerships. Another aspect of supporting partnerships is the allocation and distribution of grant funds for their development. Despite the importance of the implemented support measures, they are aimed at solving specific problematic issues, but they are not an instrument for implementing the strategy for the development of agricultural use zones, especially in terms of monitoring and managing the environmental functions of these zones, as a buffer smoothing the mutual influence of agricultural land and the urban environment.

Paragraph 3 of Article 26 of Federal Law No. 217-FZ specifies the rights and forms of interaction of state and municipal agencies with gardening and horticultural non-profit partnerships, which, in fact, exclude the possibility of strict management of the activities of these partnerships, except in cases of direct violation of current legislation. Accordingly, to achieve the strategic and tactical goals of sustainable development of urban and suburban economy, only the so-called "soft" management is applicable. In modern management system, soft management primarily concerns corporate communications and is implemented by introducing a flexible system of interaction between the manager and performers $[2,13$, 20]. The concept of "soft" management (indirect, guiding, restoring the ecological balance) is used in nature management to denote the management of natural processes that will help achieve the desired natural chain reactions. From the point of view of socio-economic effect, soft management is preferable then "hard", technogenic, but it requires more time to get a result $[12,22,25]$.

In the relations between the government agencies and horticultural non-profit partnerships, the application of soft management may include a number of actions. First of all, the municipal agencies at the base on scientific data, monitoring the state of ecosystems of suburban territories, would develop a perspective program for the development of this zone, considering its ecosystem functions $[11,26]$. Thus, a complex of socio-ecological systems (SES) based on the interaction of man and nature will be formed around the residential area of the city, which is the key to the sustainable use and conservation of nature $[4,9]$.

Rational management of socio-ecological systems is the key to the formation of socioecological production landscapes (SEPL) and the provision of various ecosystem services $[1,8]$. A prerequisite for the reasonable management of SES is the formulation of the goals of this management $[23,24]$. 


\section{Summary}

The purpose of creating and supporting of socio-ecological systems in the agricultural use zone and suburbs is the formation of a sustainable complex of natural and social conditions for gardening and recreation of residents; optimization of the belt of lands separating the city from agricultural land to reduce the impact of negative environmental factors on urban ecosystems (wind restriction, fire safety, pests, etc.); the use of these lands as carbon landfills for the capture and retention of carbon dioxide [19], the amount of which is especially high in cities due to transport emissions.

Based on the stated goals, the list of measures necessary to achieve them includes the following actions:

- comprehensive analysis and further monitoring of the state of socio-ecological systems;

- creation of a scientifically based program for the transformation of agricultural land, based on the goals set out above;

- development of the infrastructure of the agricultural use zone of the city to increase the availability of land plots and simplify the delivery of necessary materials, ensure uninterrupted supply of water and energy resources to the territory;

- organization of supplies of soils and grounds of a certain type at low prices on the terms of pre-order for the formation of a stable productive soil cover of gardens;

- supplies of planting material at low prices for the formation of tree plantations within the partnerships or along their borders to optimize the forest frame of the territory, reduce wind and water erosion of soils;

- supplies of seed material of varieties adapted to the conditions of the region at low prices;

- strengthening control over the targeted use of suburban areas, including in terms of combating quarantine weeds;

- investment on a grant basis of non-profit partnerships actively working in the direction of the formation of carbon polygons.

Thus, using soft management, municipal agencies will be able to create conditions for forming a system of socio-ecological industrial landscapes that meets modern requirements for environmental greening.

\section{References}

1. P. Arias-Arévalo, E. Gómez-Baggethun, B. Martín-López, M. Pérez-Rincón, Widening the evaluative space for ecosystem services: A taxonomy of plural values and valuation methods, Environ. Values, 27, 29-53 (2018)

2. S. Azim, A. Gale, T. Lawlor-Wright, R. Kirkham, A. Khan, M. Alam, The importance of soft skills in complex projects, International Journal of Managing Projects in Business, 3 (3), 387-401 (2010)

3. S. Barles, Urban metabolism of Paris and its region, Journal of industrial ecology, 13(6), 898-913 (2009)

4. F. Berkes, C. Folke, Linking social and ecological systems for resilience and sustainability, Linking Social and Ecological Systems: Management Practices and Social Mechanisms for Building Resilience, 13-20 (1998)

5. M. Carter, E. Gregorich, Soil Sampling and Methods of Analysis (2007). Access mode: https://doi.org/10.1201/9781420005271

6. A. Chibilev et al., Encyclopedia "Orenburgie" (2000)

7. Z. Chun-yang, I. Shu-hua, J. Peng, Relationships between urban green belt structure and temperature-humidity effect, Yingyong Shengtai Xuebao, 22(5) (2011) 
8. R. Costanza, R. de Groot, P. Sutton, S. van der Ploeg, S. Anderson, I. Kubiszewski, S. Farber, R. Turner, Changes in the global value of ecosystem services, Glob. Environ. Chang., 26, 152-158 (2014). Access mode: 10.1016/j.gloenvcha.2014.04.002

9. R. de Groot, R. Alkemade, L. Braat, L. Hein, L. Willemen, Challenges in integrating the concept of ecosystem services and values in landscape planning, management and decision making, Ecol. Complex., 7, 260-272 (2010). Access mode: $10.1016 /$ j.ecocom.2009.10.006

10. M. Deakin, A. Reid, Smart cities: Under-gridding the sustainability of city-districts as energy efficient-low carbon zones, Journal of Cleaner Production, 173, 39-48 (2018)

11. D. Fedorova, M. Safonov, N. Nazarova, B. Ukenov, Restoration of woodland belts and sustainable development of agroecosystems of steppe zone of the Orenburg oblast (Russia), IOP Conf. Series: Earth and Environmental Science (2021)

12. C. Jabbour, D. Renwick, The soft side of environmentally-sustainable organizations, RAUSP Management Journal, 53, 622-627 (2018)

13. U. Lenka, D. Suar, P. K. J. Mohapatra, Soft and hard aspects of quality management practices influencing service quality and customer satisfaction in manufacturingoriented services, Global Business Review, 11(1), 79-101 (2010)

14. D. Morgunov, Topical issues of agricultural use of the lands of settlements, Journal of Russian Law, 10 (142) (2008)

15. L. Ovtschintseva, The economic significance and social role of garden associations, Regional economy: theory and practice, 3 (2012)

16. S. Pankova, A. Tscypin, Statistical study of long-term trends in agriculture in the Orenburg region, Economic analysis: theory and practice, 29 (380) (2014)

17. V. Pryzukova, M. Tjukhova, V. Nosikov, Methods for determining mobile organic matter (humus) in soils, Fertility (Plodorodyje), 6 (2008)

18. F. Rebele, Urban ecology and special features of urban ecosystems, Global ecology and biogeography letters, 173-187 (1994)

19. L. Tretyakova, N. Azarova, N. Lavrikova, M. Opara, A. Tsvyrko, Formation of mechanisms for creating innovative national polygons, IOP Conference Series: Earth and Environmental Science, 808 (1) (2021)

20. C. Truss et al, Soft and hard models of human resource management: a reappraisal, Journal of management studies, 34 (1), $53-73$ (1997)

21. E. Tscvetkova, Prospects for the development of horticulture in Russia, Actual problems and prospects of business development, 347-350 (2018)

22. T. Uehara, T. Hidaka, T. Tsuge, R. Sakurai, M. Cordier, An adaptive social-ecological system management matrix for guiding ecosystem service improvements, Ecosystem Services, 50 (2021)

23. T. Uehara, J. Niu, X. Chen, T. Ota, K. Nakagami, A sustainability assessment framework for regional-scale Integrated Coastal Zone Management (ICZM) incorporating Inclusive Wealth, Satoumi, and ecosystem services science, Sustain. Sci., 11, 801-812 (2016). Access mode: 10.1007/s11625-016-0373-5

24. T. Uehara, K. Mineo, Regional sustainability assessment framework for integrated coastal zone management: Satoumi, ecosystem services approach, and inclusive wealth, Ecol. Ind., 73, 716-725 (2017). Access mode: 10.1016/j.ecolind.2016.10.031

25. D. Waltner-Toews et al., The ecosystem approach: Complexity, uncertainty, and managing for sustainability (2008) 
26. Z. Zhou, M. Li, Spatial-temporal change in urban agricultural land use efficiency from the perspective of agricultural multi-functionality: A case study of the Xi'an metropolitan zone, Journal of Geographical Sciences, 27(12), 1499-1520 (2017) 